\title{
HISTÓRIA, MEMÓRIA, PSICANÁLISE: PENSANDO OS DESDOBRAMENTOS DO PASSADO TRAUMÁTICO DA GUERRA CIVIL, DO FRANQUISMO E DA TRANSIÇÃO A DEMOCRACIA NA ESPANHA
}

\author{
History, memory, psychoanalysis: thinking of the unfolding of the traumatic past of the civil \\ war, the Franco regime and the transition to democracy in Spain
}

Filipe Cambraia do Canto*

\begin{abstract}
Resumo: o presente trabalho debruça-se sobre os desdobramentos da guerra civil, do franquismo e da transição à democracia na Espanha. $\mathrm{O}$ esforço teórico deste ensaio reside na tentativa de aproximar a história de outros dois campos do saber, quais sejam, a memória e a psicanálise. Segundo procuraremos mostrar, é este diálogo com a memória e com a psicanálise, com suas distintas visadas ao passado, que enriquece e fortalece a historiografia, apta quem sabe a dar ao passado uma narrativa que a carga traumática frequentemente veda. Este movimento é realizado através de três textos que são aproximados: um capítulo de $O$ Impostor, no qual Javier Cercas esboça as trocas entre memória e história; um texto do historiador espanhol Ricard Vinyes, em que ele analisa as ações do Estado e suas consequências desde o período transicional até meados dos anos 2000; e, finalmente, um texto de Dominick Lacapra, em que são analisados alguns conceitos psicanlíticos, bem como sua utilidade para a história.
\end{abstract}

Palavras-chave: história, memória, psicanálise.

\begin{abstract}
Francoism regime and the transition to democracy in Spain. The theoretical effort of this essay lies in the attempt to bring history closer to two other fields of knowledge, namely, memory and psychoanalysis. As we will try to show, it is this dialogue with memory and with psychoanalysis, with its distinct aims to the past, that enriches and strengthens historiography, apt to give to the past a narrative that the traumatic burden often closes. This movement is carried out through three texts that are put in dialogue: a chapter of The Impostor, in which Javier Cercas sketches the exchanges between memory and history; a text by the Spanish historian Ricard Vinyes, in which he analyzes the actions of the State and its consequences from the transitional period until the mid-2000s; and finally, a text by Dominick Lacapra, in which some psychoanalytic concepts are analyzed, as well as their usefulness to history.
\end{abstract}

Keywords: history, memory, psychoanalysis.

A título de introdução, gostaria de iniciar esse ensaio com um traçado bastante panorâmico dos temas e textos que serão abordados nas páginas que estão por vir. Assim, o laço que une e amarra os diferentes textos a serem analisados é justamente o dos passados traumáticos; em especial, nesse caso, o passado recente da Espanha, que gira em torno de seus eventos e processos históricos mais significativos no século $\mathrm{XX}$ : a guerra civil, o franquismo e a transição à democracia.

De modo geral, a análise dos passados traumáticos tem sido uma temática recorrente entre os historiadores do tempo presente - especialmente desde as décadas de 1970 e 1980 -

\footnotetext{
${ }^{*}$ Mestrando em História pela UFRGS. O autor é também bolsista CAPES.
} 
que têm tido de se haver, em seu trabalho, com os desdobramentos dos regimes totalitários que marcaram o século XX. Este movimento, esta inflexão reflexiva vieram acompanhados de novas abordagens teóricas, como uma aproximação da história com a memória, bem como da mobilização de parte do arcabouço conceitual oriundo da psicanálise, que decerto ajuda a pensar os eventos traumáticos, devolvendo-lhes assim uma possibilidade narrativa. Este ensaio não tem outro objetivo senão o de tentar mostrar e refletir o modo pelo qual, segundo acredito, os três textos a serem analisados nos ajudam a perceber tanto a interação da história com a memória, como as possíveis e profícuas trocas entre história, memória e psicanálise. A esta dupla temática vem somar-se uma terceira, que entrecruza-se sem cessar com as demais: o papel social atribuído às testemunhas neste novo tempo que, evocando a elegante fórmula de Annette Wiewiorka, chamarei com ela de era da testemunha. ${ }^{1}$ Apresentemos então os trabalhos que conformam meu objeto de investigação.

O primeiro texto selecionado é um capítulo do livro $O$ Impostor, ${ }^{2}$ de Javier Cercas, romancista espanhol que vem se notabilizando cada vez mais por seus livros, que em geral abordam a história recente da Espanha e, consequentemente, o passado traumático da guerra civil e do franquismo, assim como o fenômeno memorial comum em certa medida a toda Europa e bem conhecido dos historiadores contemporâneos. ${ }^{3}$ Trata-se de um capítulo fundamental do livro em questão, na medida em que nele seu autor esboça, ainda que de maneira lacunar e paradoxal - conforme procurarei mostrar -, os modos pelos quais, em seu entendimento, história e memória interagem. Pensar sobre a natureza dessa relação entre memória e história é relevante por alguns motivos: internamente ao livro de Cercas, porque é possível demonstrar como os pressupostos teóricos por ele desenvolvidos levam-no a alguns equívocos, como podemos perceber em suas reflexões mais gerais acerca da onda memorial na Espanha; mas também porque, ao se debruçar sobre as interações entre memória e história, o texto de Cercas permite, apesar de tudo, uma aproximação com os demais textos que serão aqui

\footnotetext{
${ }^{1}$ WIEVIORKA, Annette. The era of the witness. Ithaca: Cornell University Press, 1. ed., 2006.

${ }^{2}$ CERCAS, Javier. O Impostor. São Paulo: Biblioteca Azul, 1. ed., 2015, p. 291-300.

${ }^{3}$ Ora, acontece que $O$ Impostor é justamente um dos desdobramentos da onda memorial na Espanha. Publicado originalmente em 2014, O Impostor é um dos trabalhos mais importantes de Cercas. Trata-se de uma obra que pretende narrar a biografia desse "impostor", o nonagenário catalão Enric Marco Batlle, que por uma série de mentiras ou imposturas mantidas de 1978 até 2005 pôde ganhar notoriedade no seio da sociedade espanhola. Pois Enric Marco apresentava-se como um contumaz resistente ao franquismo, um deportado para os campos de concentração nazistas, entre outras inverdades desse gênero. E como se acreditou nelas, Marco acabou se notabilizando, concedendo inúmeras entrevistas a jornalistas, proferindo palestras em escolas e universidades, chegando mesmo a presidir a maior associação espanhola de sobreviventes dos campos de concentração nazistas, a Amical de Mauthausen, sediada em Barcelona. De um modo geral, a questão que Cercas se propõe a responder ao longo do livro, e que aparece particularmente destacada no capítulo selecionado é a de 'por que a impostura de E. Marco pôde perdurar por quase trinta anos?' O que este fato revela da conjuntura espanhola?
} 
analisados. Denota-se, portanto, a atualidade da temática referida. Não obstante, o primeiro texto selecionado trata ainda de um tema muito caro ao debate acerca da onda memorial, presente também no segundo texto escolhido: o protagonismo da vítima e da testemunha.

O segundo texto, intitulado 'La memoria del Estado', 4 é de Ricard Vinyes, historiador destacado no contexto universitário espanhol e estudioso atento dos desdobramentos do passado da guerra civil, do franquismo e da transição no seio da sociedade espanhola. O que convém inicialmente sublinhar do trabalho de Vinyes é a maneira como ele relaciona história e memória a partir de uma noção de complementaridade, evocando para tanto A memória, a história, o esquecimento, livro incontornável de Paul Ricoeur. Vinyes mostra como a história deve enriquecer-se a partir do diálogo com outros campos do saber, lembrando que a memória é justamente um desses campos. Livrando assim a história de uma 'hybris' epistemológica e de uma vontade de se erigir em saber absoluto, Vinyes acaba por implicitar inclusive que, para além dos pressupostos estritamente acadêmicos, os historiadores devem também se pautar por uma atitude ética frente a seus objetos de estudo. A história engendra um conhecimento verificado e verificável, mas não verdades absolutas e atemporais. ${ }^{5}$ Não é neutra e, tampouco, apolítica. Nesse sentido, ele parece dissociar-se inteiramente de Cercas, conforme veremos. Tal abertura ético-política possibilita uma análise de como o Estado espanhol - desde a transição até o fim dos anos 2000 - tem agido em relação às memórias traumáticas, bem como o modo pelo qual suas ações se refletem no fenômeno do primado da testemunha. Para Vinyes, o maior perigo advindo do primado da testemunha é o de impedir a ressignificação das memórias e, portanto, a adoção de uma perspectiva ética no trato com o passado que lide não apenas com as vítimas mas que vise, em especial, o cidadão.

Isso nos remete ao último texto, de Dominick Lacapra. Trata-se do capítulo final de seu Historia y memoria después de Auschwitz, intitulado 'Psicoanálisis, memoria y el giro ético' ${ }^{6}$ A passagem à psicanálise torna-se consequente nesse ensaio por pelo menos duas razões: em primeiro lugar porque a história, ao aproximar-se da memória, torna-se apta a entrecruzar-se com outros campos do saber que dialogam com ela; em segundo, na medida em que a ressignificação das memórias apregoada por Vinyes pode ser vista como uma espécie de 'elaboração' do passado traumático. O conceito psicanalítico de elaboração pressupõe uma confrontação com dada memória recalcada, reprimida. Tal confrontação, quando exitosa,

\footnotetext{
${ }^{4}$ VINYES, Ricard. 'La memoria del Estado'. In: VINYES, Ricard (editor). El estado y la memoria: gobiernos y ciudadanos frente a los traumas de la historia. Barcelona: RBA Libros, S. A., 1. ed., 2009, p. 23-66.

5 Ibidem, p. 33.

${ }^{6}$ LACAPRA, Dominick. 'Psicoanálisis, memoria y el giro ético' In: LACAPRA, Dominick. Historia y memoria después de Auschwitz. Buenos Aires: Prometeo Libros, 1. ed., 2009, p. 207-239.
} 
possibilitaria a assimilação, uma apropriação de tal memória que, a partir daí, pode então ser ressignificada. No horizonte da elaboração encontra-se o trabalho de luto. Creio que essa aproximação da história com a psicanálise seja benéfica especialmente quando o objeto de análise vem a ser um evento ou processo traumático, como a memória acerca do franquismo e da guerra civil o são. Não obstante isso, os trabalhos de Vinyes e de Lacapra manifestam preocupações muito claras com os aspectos éticos e políticos da contribuição historiográfica para um melhor entendimento e mesmo quem sabe a superação desses passados que não passam. Por fim, uma última preocupação no que tange à associação da história com a psicanálise reside na transposição sempre problemática dos conceitos psicanalíticos - forjados para a análise dos indivíduos - para a análise das sociedades. Questão que pretendo abordar, ainda que muito brevemente, em minha análise do texto de Lacapra. Findas as assertivas de caráter introdutório, passemos à análise dos textos já destacados.

\section{ANALISE DO PRIMEIRO TEXTO}

No segundo capítulo ${ }^{7}$ da terceira parte de seu livro, intitulada significativamente "O voo de Ícaro", Cercas questiona-se sobre como pôde o impostor ascender hierarquicamente em associações memoriais, e sobre como, em especial, puderam suas mentiras perdurar por tanto tempo. Destaco dois elementos de sua resposta. Primeiro: um dos fatores que tornaram "o caso Marco possível foi a nossa relativa ignorância do passado recente em geral e do nazismo em particular". ${ }^{8}$ Assim, embora "Marco se vendesse como um remédio contra esse mal nacional, ele era, na realidade, a maior prova de sua existência". 9 Segundo: a emergência de um fenômeno que Cercas irá nomear, a meu ver um tanto exageradamente, de "chantagem da testemunha". Resumindo o argumento crítico de Cercas, a importância da testemunha estaria numa espécie de crença segundo a qual ela teria inevitavelmente mais a dizer sobre um dado evento, na medida em que o vivenciou. A "chantagem" residiria num poder de constrangimento emanado da testemunha e dirigido a seus potenciais interlocutores; questionar determinado testemunho seria algo semelhante a desmerecer o sofrimento da vítima. O desdobramento natural dessa situação seria o congelamento do debate acerca das memórias traumáticas, bem como a extrapolação do papel da testemunha. ${ }^{10}$

\footnotetext{
${ }^{7}$ CERCAS, Javier. Opus Cit., p. 291-300.

${ }^{8}$ Ibidem, p. 292.

9 Idem.

${ }^{10}$ Esse constrangimento em questionar a testemunha pode ser observado, segundo Cercas, no próprio episódio em que Marco faz seu pedido de ingresso na Amical. Os documentos apresentados são inconclusivos e algumas declarações dadas pelo impostor, mentirosas. Ele mente, apenas para citar um exemplo, sobre o dia de seu nascimento: diz ter nascido em 14 de abril de 1921, quando na verdade nasceu dois dias antes, fazendo assim com
} 
No entanto, o que eu gostaria de sublinhar é justamente a maneira como estas análises são feitas. Elas causam alguma estranheza e merecem ser vistas de perto. Antes, contudo, é necessário instrumentalizá-las com o debate que gira em torno da relação entre memória e história. Assim, parece problemático que em O Impostor não haja um delineamento muito claro sobre a natureza desta relação; por vezes, ela é abordada de modo não só lacunar, mas paradoxal ou contraditório. Aquilo que motiva Cercas a esboçar tal relação seria a ameaça iminente de que a memória, em seu frenesi, possa chegar a substituir a história. Ele diz:

[...] em um tempo saturado de memória, esta última ameaça substituir a história. Tema difícil. Memória e história são, por princípio, coisas opostas: a memória é individual, parcial e subjetiva; a história, por sua vez, é coletiva e aspira a ser total e objetiva. Memória e história são também complementares: a história dota a memória de um sentido; a memória é um instrumento, um ingrediente, uma parte da história. [Grifo meu]. ${ }^{11}$

Em primeiro lugar, é evidenciado o posicionamento de Cercas sobre o caráter de oposição entre memória e história, não só em função de que, "por princípio", elas sejam opostas, mas também porque, no estabelecimento feito por ele de um confronto entre ambas, a história correria o risco de desaparecer. Isto parece um pouco exagerado. Mas há outros pontos problemáticos neste excerto. É muito discutível dizer, por exemplo, que a memória é (apenas) individual $^{12}$ e que a história aspira a ser total e objetiva. ${ }^{13} \mathrm{E}$, no entanto, é deste argumento que Cercas tira a lição de complementaridade entre ambas: a memória como mero instrumento, uma parte da história. A história seria, assim, duplamente superior à memória. Primeiro porque aspira à totalidade e à objetividade, sendo portanto muito mais confiável do que a memória, parcial e subjetiva; e também porque ela abarca a memória, que é apenas uma de suas partes.

Destarte, as formulações de Cercas sobre história e memória carecem de clareza. De modo que se torna lícito apontar uma certa correspondência entre esse esboço teórico ultrapassado e as repostas fornecidas por ele à pergunta de por que a falsificação memorial de

\footnotetext{
que seu aniversário coincidisse com o da Segunda República Espanhola, proclamada em 14 de abril de 1931. Sobre o caráter inconclusivo da documentação apresentada por Marco, Cercas assevera que "ou ninguém sabia alemão na Amical de Mauthausen, ou ninguém leu os documentos, ou quem os leu considerou-os convincentes, ou não os considerou convincentes mas não queria ser estraga-prazeres nem pôr o dedo na ferida, e cedeu ao prestígio [...] ou à chantagem da testemunha e não se atreveu a dizer Não, preferindo silenciar”. Ibidem, p. 304

${ }^{11}$ Ibidem, p. 298.

12 "Nossas lembranças permanecem coletivas e nos são lembradas por outros, ainda que se trate de eventos em que somente nós estivemos envolvidos [...]. Isto acontece porque jamais estamos sós." HALBWACHS, Maurice. A memória coletiva. São Paulo: Centauro, 2. ed., 8. reimpressão, 2015, p. 30. Ainda que a ênfase dada por Halbwachs aos aspectos coletivos da memória possa ser exagerada, como mostra P. Ricoeur em A memória, a história, o esquecimento, seria igualmente exagerado não levar tais aspectos em conta.

${ }^{13}$ Sob o signo de sua operação historiográfica, Michel de Certeau assinala que a história só é legítima na medida em que reconhece tanto as imposições de seu lugar de produção, como as parcialidades de sua prática e as inversões de sua escrita. Afirmar, portanto, que a história é total e objetiva é o mesmo que reatualizar uma desconfiança acerca de sua legitimidade. Ver CERTEAU, Michel de. A Escrita da História. Rio de Janeiro: Forense, 2. ed., 3. reimpressão, 2013, p. 45-111.
} 
Enric Marco perdurou por tanto tempo. Tal correspondência fica ainda mais nítida na medida em que as próprias saídas elaboradas por Cercas a esta questão resultam problemáticas. Vejamos as duas principais já anteriormente mencionadas.

Na primeira delas, é dito que Marco se apresentava como remédio, mas que na verdade ele era um sintoma do mal representado pela ignorância acerca do passado recente. Uma vez que este trecho pertence ao mesmo capítulo em que memória e história são confrontadas, fica a pergunta se Cercas não está sugerindo justamente que o conhecimento historiográfico atue como remédio contra esta ignorância. Em caso positivo, isto poderia desdobrar-se num impasse. Não porque a história não possa servir de antídoto a uma memória hipertrofiada como a de E. Marco, mas em função de que, segundo Cercas, ela tenderia à objetividade e à totalidade, aproximando-se assim da "verdade perfeita", da "verdade absoluta, que é a soma de infinitas verdades parciais [...]". ${ }^{14}$ As investigações de uma história como esta que é desenhada, necessariamente superior e mais confiável do que a memória, poderiam fechar as portas para um debate tão importante como o das memórias traumáticas, criando, paradoxalmente, o mesmo efeito que vemos na "chantagem da testemunha": a impossibilidade de uma discussão sempre renovável em virtude da inquestionabilidade de certos pressupostos. Talvez seja necessário lembrar que também a história pode ser excessiva e exigir antídotos, tal como Nietzsche escreveu em sua Segunda Consideração Intempestiva; e, da mesma maneira, que as verdades historiográficas são mais produzidas que descobertas, pois ao narrar acontecimentos, o historiador constrói uma inteligibilidade à medida que os seleciona, ordenando assim o caos de uma sucessão de momentos para o qual seria impossível sequer precisar seu início ou fim. ${ }^{15}$

Não obstante, Cercas nos diz que a impostura de Marco pôde perdurar no tempo em razão da "chantagem da testemunha". Aqui, o que provoca estranheza não é tanto esta constatação em si, mas a utilização do termo “chantagem”, pejorativamente carregado. Gostaria de salientar brevemente um elemento que me pareceu contraditório nesta análise, e que mereceria uma investigação mais profunda: de um lado, o autor de $O$ Impostor mostra-se ambivalente em relação a E. Marco. De outro, porém, tal ambivalência ou mesmo ambiguidade parece não ser mantida em suas considerações sobre a conjuntura espanhola. Assim, Marco é adjetivado ora como "charlatão desaforado, manipulador sem vergonha, lambe-botas inescrupuloso", ${ }^{16}$ ora como uma espécie de D. Quixote contemporâneo e melhorado, pois

\footnotetext{
${ }^{14}$ CERCAS, Op. Cit., p. 299.

${ }^{15}$ RICOEUR, Paul. Tempo e Narrativa 1: a intriga e a narrativa histórica. São Paulo: Martins Fontes, 1. ed., 2. tiragem, 2012, p. 114.

${ }^{16}$ CERCAS, Op. Cit., p. 40-41.
} 
diferentemente do cavaleiro da triste figura, que não iludia ninguém a não ser a si mesmo, Marco conseguiu não apenas enganar seu país por quase trinta anos, mas ainda tornar-se uma figura respeitável, o presidente da Amical de Mauthausen. ${ }^{17}$ A mentira de Marco é também relativizada, uma vez que ele não teria feito muito mais que "atender a uma demanda massiva vagamente esquerdista de uma ração sentimental venenosa temperada com um pouco de boa consciência histórica". ${ }^{18}$ Marco seria ainda um homem simultaneamente excepcional e ordinário. Excepcional em virtude da energia e inventividade de que precisou para manter sua falsificação por quase três décadas; mas absolutamente comum na medida em que, no final da década de 1970, marcada pelo fim do franquismo e pela transição à democracia, todos os espanhóis estariam inventando seus próprios passados em maior ou menor grau, limpando assim uma nódoa de colaboracionismo e apatia. ${ }^{19}$ Parece haver, portanto, um desequilíbrio na análise de Cercas. Há um desconforto em relatar as atitudes de seu biografado; e ele justifica seu relato ao dizer que escrever sobre Marco não é necessariamente o mesmo que redimi-lo, mas uma tentativa de compreendê-lo. Esforço que, suspeita-se, não foi repetido na avaliação conjuntural da Espanha.

Agora que a análise do texto de Cercas foi empreendida e suas contradições, expostas, fica facilitada a tarefa de demonstrar a maneira pela qual ele pode ser associado aos demais textos. Contudo, e apesar de suas evidentes fragilidades, gostaria de assinalar uma vantagem que o trabalho de Cercas tem sobre os de Vinyes e de Lacapra: a de ter alcançado o grande público espanhol. Pois se é verdade, conforme Vinyes e Paloma Aguilar assinalam em muitos de seus trabalhos, que ainda não há, salvo honrosas exceções, um debate público satisfatório na Espanha sobre os desdobramentos mais atuais da guerra civil e do franquismo, torna-se lícito pensar que o livro de Cercas tem contribuído para tornar mais abrangente a discussão em torno das memórias traumáticas e do primado da testemunha. Isso ocorre por duas razões: porque Javier Cercas é um escritor muito destacado na Espanha, vencedor de diversos prêmios literários, cujas obras vêm sendo traduzidas para mais de trinta idiomas; e também em função de Enric Marco, o biografado de $O$ Impostor, que acabou se tornando uma figura pública na sociedade espanhola.

\footnotetext{
${ }^{17}$ Ibidem, p. 245-252.

18 Ibidem, p. 43.

${ }^{19}$ Ibidem, p. 250-252. Seria interessante notar um comentário do historiador Ricard Vinyes referente a este tema. Num texto de apenas três páginas, e consternado com a visão de Cercas sobre a suposta colaboração massiva dos espanhóis para com o franquismo, ele ironiza: ‘¿Acaso el autor tiene como paradigma de rebelión el pueblo permanentemente en armas y en pie? ¿De veras? ¿Su modelo de dignidad política es el Ulster de antaño?’. VINYES, Ricard. J. Cercas o el Tratante de verdades. Disponível em http://revistes.ub.edu/index.php/ACS/article/view/12337/15096. Último acesso em 10 out. 2016.
} 
Portanto, uma primeira razão para a abordagem historiográfica do livro de Cercas reside justamente no fato de que ele alarga o alcance demasiado pequeno das discussões acadêmicas sobre os passados traumáticos. Isso posto, cabe demonstrar como os textos acadêmicos a serem analisados podem vir em auxílio na identificação de alguns equívocos nos esboços teóricos formulados por Cercas. De um lado, vemos que o autor de $O$ Impostor enxerga com alguma clareza a conjuntura memorial na Espanha, da qual a impostura de E. Marco não é senão um sintoma. De outro, contudo, parece que não há nenhum antídoto possível à onda memorial, na medida em que história e memória estão posicionadas segundo um critério de oposição em que a "vitória" de uma culminaria no desaparecimento da outra. O texto de Vinyes oferece uma série de ajustes a esse ponto de vista bastante problemático (lembrando que o diálogo entre os textos ora apresentados é de minha inteira responsabilidade). Não obstante isso, é possível pensar ainda que o apoio de alguns conceitos psicanalíticos como os de elaboração, trabalho de luto, trabalho de memória, compulsão à repetição, entre outros, possa auxiliar o historiador no tratamento de temas espinhosos como esse dos passados traumáticos - ponto que abordarei adiante.

\section{ANÁLISE DO SEGUNDO TEXTO}

O texto que vou analisar é o primeiro capítulo da coletânea El Estado y la Memoria, livro publicado em 2009 e que reúne uma série de trabalhos que giram em torno dos passados traumáticos e do modo pelo qual as memórias desses passados são elaboradas tanto na Europa como na América Latina. Trata-se de um esforço interdisciplinar - especialmente entre as áreas das ciências humanas e da psicologia - cujo escopo não é outro senão o de compreender melhor a forma que assumem os desdobramentos desses passados no presente e, igualmente, de apontar algumas saídas para o futuro. O texto de Ricard Vinyes, intitulado "La memoria del Estado", está orientado, portanto, em consonância com essa preocupação geral. Num nível mais específico, seu texto articula os vários contextos muito similares entre si acerca da memória da guerra civil e do franquismo na Espanha através de dois marcos basilares: a Lei de Anistia, de outubro de 1977 e a Lei de Memória Histórica, promulgada trinta anos depois. Vinyes está particularmente interessado em analisar o papel do Estado na gestão dessas memórias traumáticas e de seus desdobramentos, sendo o mais importante deles o protagonismo que ele vê ser atribuído a esse curioso personagem, o "sujeito-vítima". Conforme tentarei mostrar, é justamente a ênfase dada por ele às ações do Estado em tudo o que toca às memórias traumáticas que lhe permitirão chegar a conclusões mais fecundas que aquelas elaboradas por Javier Cercas. Meu objetivo aqui será o de investigar como o texto de Vinyes corrige e amplia alguns 
pressupostos teóricos de Javier Cercas e, da mesma maneira, apontar para algumas aberturas existentes nesse texto a um enfoque psicanalítico. Essa última ramificação não é exatamente tradicional na historiografia, mas permitirá decerto a análise de um trabalho de Lacapra, historiador que dedicou parte significativa de seus esforços a esboçar um entrecruzamento profícuo entre a história e a psicanálise.

Vinyes inicia seu texto com a tentativa de contextualizar o período transicional, situado na segunda metade dos anos 1970, que culminou na Lei de Anistia. Seu interesse recai sem dúvida nas ações estatais e nas suas implicações para o regime democrático restabelecido. ${ }^{20}$ Mas as críticas dirigidas ao Estado espanhol são duríssimas. Assim, para o historidor espanhol, é em virtude da inibição do Estado em estabelecer políticas públicas de memória que produziuse à época da Anistia uma impunidade equitativa, que redundou numa simetria entre ditadura e democracia. Além de obscurecer as fronteiras entre democracia e ditadura, esta simetria teria impedido que o passado passasse, instaurando com isto um vazio ético, na medida em que impossibilitou que as memórias traumáticas fossem amplamente discutidas num debate que explorasse as diferenças entre os valores democráticos e aqueles que embasaram o franquismo, relegando-as assim à esfera da vida privada dos indivíduos.

Mas como isso acontece? Basicamente, pela instituição organizada pelo Estado daquilo que Vinyes denomina de 'boa memória', isto é, uma economia memorial destinada a evitar os conflitos de memória. Pois, no contexto da transição e da Lei de Anistia, nem o conhecimento dos horrores e da devastação ética provocados pelo franquismo, nem a restituição social e moral da resistência e tampouco o desejo de informação e debate (de alguns setores sociais mais atentos a essas questões) sobre o passado foram considerados pelo Estado. Ao contrário, tais demandas sempre foram vistas como um perigo à convivência, devendo ser apaziguadas pelo bem da cidadania. ${ }^{21} \mathrm{E}$, embora o recém instaurado Estado democrático não tenha trabalhado diretamente no sentido de ocultar eventos sobre o passado, sua atuação limitou-se a dar como socialmente superado qualquer passado conflituoso.

Vinyes assinala que o poder público se inibiu de cumprir o papel que deveria desempenhar: não tanto o de resolver a competição entre memórias existentes, mas o de criar o

\footnotetext{
${ }^{20}$ Para um panorama mais amplo referente aos temores de boa parte da população espanhola de que o passado da guerra civil pudesse se repetir caso não fosse organizada uma transição pacífica à democracia, ver AGUILAR, Paloma. Justicia, política y memoria: los legados del franquismo en la transición española. In: Centro de Estudios Avanzados en Ciencias Sociales. Madrid: Series 2001/163, 60 páginas; Los debates sobre la memoria histórica. In: Claves de Razón Práctica, $\mathrm{n}^{\circ}$ XX. https://www.academia.edu/9740546/LOS_DEBATES_SOBRE_LA_MEMORIA_HIST\%C3\%93RICA. Último acesso em 10 out. 2016.

${ }^{21}$ VINYES, Ricard. 'La memoria del Estado'. In: VINYES, Ricard (editor). El estado y la memoria: gobiernos y ciudadanos frente a los traumas de la historia. Barcelona: RBA Libros, S. A., 1. ed., 2009, p. 25.
} 
marco adequado para que o conjunto da cidadania compreendesse o conflito, valorasse-o a fim de trabalhar com ele, de expô-lo e, em suma, elaborá-lo. ${ }^{22}$ Para Vinyes, o Estado democrático espanhol não teria cumprido sua vocação pública em razão de duas frágeis alegações: a) evitar conflitos desnecessários à sociedade; b) respeitar a 'pluralidade' de memórias, evitando qualquer intromissão estatal. Eis a refutação das justificativas estatais: a) a (in)ação do poder público teria gerado vários conflitos entres os diferentes grupos identitários, cujas reivindicações desdobraram-se amiúde em exigências impróprias, baseadas na pretensão de que neles - em cada um desses grupos - repousa a autoridade da memória; b) essa inibição do Estado, por outro lado, tampouco teria garantido qualquer pluralidade de memórias. Logo, tanto os conflitos entre memórias dissidentes como a impossibilidade do reconhecimento da pluralidade intrínseca à memória teriam derivado de um déficit do debate verdadeiramente crítico, público e plural, dirigido ao conjunto da sociedade, acerca do passado da guerra civil e do franquismo. Em vez de enfrentar o passado, confrontá-lo, a insuficiência da discussão pública teve o efeito de uma circunscrição de tais memórias ao âmbito privado, fazendo enfim com que os cidadãos, em sua maioria, perdessem de vista ou mesmo fossem impossibilitados de perceber as reais dimensões do trauma infligido pelas violências da guerra e da ditadura.

Não obstante, surge na virada do século um renovado interesse sobre o passado por parte da população. Vinyes observa a confluência de vários elementos distintos nesse processo: o conhecimento produzido no âmbito acadêmico, a discussão empreendida pelos meios de comunicação, o trabalho das associações memoriais e, especialmente, o fator geracional. $\mathrm{O}$ historiador espanhol destaca o interesse e a curiosidade das gerações que não vivenciaram diretamente os eventos traumáticos do passado, e que, no entanto, cresceram e crescem rodeadas de relatos transmitidos por suportes variados, seja através de testemunhos, seja pelo teatro, cinema, literatura e, por que não, pelo conhecimento historiográfico. ${ }^{23}$ É nesse contexto que está situado o segundo marco basilar que norteia o texto do historiador espanhol: a Lei de Memória Histórica, promulgada em 2007. Contudo, a lei resultou decepcionante. Em especial, porque ela teria contribuído para consolidar o sujeito-vítima, evitando assim a articulação de uma política pública de memória para toda a sociedade. ${ }^{24}$ Vinyes situa como causa da consolidação desse personagem a própria limitação da lei à reparação financeira das vítimas. Assim, foi possível que o sujeito-vítima acessasse algumas modalidades de reparação econômica sem necessidade de invocar motivações políticas para argumentar sua aprovação,

\footnotetext{
${ }^{22}$ Ibidem, p. 46.

${ }^{23}$ Ibidem, p. 53.

${ }^{24}$ Ibidem, p. 37.
} 
fazendo com que a discussão tenha se centrado mais nos benefícios que no próprio sentido das reparações. ${ }^{25}$ Os eventos traumáticos eram mais uma vez esvaziados de seus elementos éticos e políticos.

Esse esvaziamento ético no debate das memórias traumáticas tem graves consequências: a mais preocupante redunda no bloqueio à ressignificação das memórias, dificultando o trabalho de luto ao conjunto da sociedade. Isso ocorreria em razão de que o prestígio da vítima e da testemunha advêm de seu sofrimento. Na medida em que o sofrimento não pode ser mensurado e que, por outro lado, o debate não é pautado por valores tais como democracia, cidadania, etc., é construído assim um dever moral que o cidadão teria a obrigação de saber e transmitir às gerações seguintes. Logo, podemos dizer com Vinyes que o sofrimento é constituído num princípio de autoridade substitutivo da razão. Portanto, uma vez que a lição do passado não adviria de valores, mas de experiências; que ela não se pauta por princípios ético e políticos, mas por sensações; na medida em que ela não se volta para o conjunto da sociedade, mas para a vítima, podemos falar em memória intransitiva. Uma memória assim não admite qualquer trabalho social, elaboração ou ressignificação; ela está fechada ao presente, já que no presente convivem gerações distintas com percepções e preocupações também distintas. E, como corolário de todo esse imperativo memorial, há uma redução de todo o debate a decisões estritamente individuais, o que exime as administrações públicas de qualquer responsabilidade. Assim, com a negativa do Estado em explicar a democracia como um bem conquistado com esforço, o passado acaba por não passar, na medida em que o trauma não é elaborado.

Resumido ainda que muito sucintamente o texto esclarecedor de Vinyes, torna-se enfim exequível a tarefa de demonstrar como sua abordagem do passado traumático espanhol lastreada num mapeamento das ações do poder público -, possibilita um ajuste aos esboços teóricos de Cercas. Assim, Vinyes aponta que embora tenha havido desde o fim dos anos 1970 um aumento significativo no número de publicações acadêmicas sobre as duras heranças da guerra e da ditadura, aumento que foi potencializado ainda mais na virada do século, não se pode asseverar que não houve desconhecimento social ou mesmo silêncio acerca dos horrores desse passado recente. Conforme Vinyes destaca, se em parte da cidadania havia uma expressão pessoal da repressão, não havia, por seu turno, um conhecimento social das verdadeiras dimensões alcançadas pela repressão ditatorial, assim como não havia um conhecimento social de como se havia resistido à ditadura. ${ }^{26}$ Logo, basear-se no frágil argumento de que houve um

\footnotetext{
25 Ibidem, p. 39.

${ }^{26}$ Ibidem, p. 31-32.
} 
acréscimo no número de publicações atinentes à guerra civil e à ditadura para afirmar que não havia desconhecimento social seria improcedente. E isso por seis razões pontuadas por Vinyes que, acredito, podem ser confrontadas com o arrazoado de Javier Cercas sobre a natureza da relação entre história e memória: a) porque isso confundiria o conhecimento historiográfico com sua socialização; b) tal argumento solenizaria uma obviedade, isto é, das diferenças entre memória e história, mas de modo a apresentar essas diferenças em termos de contraposição e exclusão recíproca; c) isso seria o mesmo que aceitar uma proposição de subordinação entre história e memória, quando na verdade a relação entre ambas estaria baseada na complementaridade, em que uma e outra enriquecem-se mutuamente a partir de suas aproximações e possibilidades distintas relativas ao passado; d) os historiadores não detêm de maneira alguma o monopólio da verdade sobre o passado; e) supondo - como quer Cercas que possa existir uma história objetiva, superior e mais confiável do que a memória, é de se supor igualmente que uma história assim justificaria sua razão de ser pela consecução de um conhecimento acabado e irrefutável, inviabilizando uma discussão sempre aberta e renovável, que possibilitasse a ressignificação das memórias traumáticas; f) tal argumento confunde conhecimento histórico com necessidade ética. ${ }^{27}$

Vemos assim que ao pensar a questão problemática dos passados traumáticos e do dever de memória na Espanha pelo viés do debate público e do papel do Estado no fomento ou não dessas discussões, o arrazoado de Vinyes acaba por ir de encontro às ideias elaboradas por Javier Cercas. Embora ambos assinalem o papel demasiado importante atribuído às testemunhas e às vítimas, Vinyes desenvolve uma visão mais realista da historiografia; sobretudo uma visão mais ampla e fecunda, porque reconhece que a produção do conhecimento historiográfico, por importante que seja, não implica necessariamente na socialização desse mesmo conhecimento. A perspectiva de Vinyes permite a aproximação não só entre história e memória, como apregoa Ricoeur, mas também entre a história e a ética, na medida em que a historiografia não encerra debates e pode contribuir, apesar de seu alcance limitado, para a ressignificação das memórias traumáticas. Essa última inflexão que aponto no trabalho de Vinyes o avizinha, como veremos, do historiador estadunidense Dominick Lacapra que, em seus trabalhos, refletiu detidamente sobre os possíveis entrecruzamentos entre história e psicanálise.

\section{ANÁLISE DO TERCEIRO TEXTO}

${ }^{27}$ Para acesso em maiores detalhes dessas seis refutações, ver ibidem, p. 32-34. 
Antes de iniciarmos a análise do texto de Lacapra, convém pontuar uma dificuldade inerente a toda tentativa de relacionar a psicanálise com a história: será lícito transpor os conceitos psicanalíticos, forjados para elucidar processos da psique dos indivíduos, à abordagem historiográfica dos passados traumáticos, cujo interesse maior está voltado à coletividade? Ricoeur lança mão de duas justificativas que considero válidas: a primeira seria a de que o próprio Freud teria aludido por diversas vezes a situações que ultrapassam a cena analítica, não se furtando a tais extrapolações em alguns de seus trabalhos conhecidos como “sociais", como Totem e Tabu, Moisés e o monoteísmo, O Futuro de uma ilusão e Mal-estar na civilização. ${ }^{28}$ Em segundo lugar, diz Ricoeur, porque "é a constituição bipolar da identidade pessoal e da identidade comunitária que, em última instância, justifica estender a análise freudiana do luto ao traumatismo da identidade coletiva." 29 A segunda justificativa parece estar inteiramente de acordo com os propósitos de Lacapra, na medida em que ele insiste que a produção historiográfica que gira em torno dos passados traumáticos não deve meramente se deter nos aspectos epistemológicos, mas estender suas preocupações com considerações éticas e, por que não, terapêuticas.

Como os trabalhos de Lacapra dispensam maiores apresentações, vou me ater doravante ao texto a ser analisado, o capítulo final de seu Historia y memoria después de Auschwitz, intitulado 'Psicoanálisis, memoria y el giro ético' ${ }^{30}$ Nesse capítulo são considerados em especial quatro conceitos psicanalíticos, a saber: luto, melancolia, elaboração e compulsão à repetição. Lacapra inicia dizendo que ao longo de seu livro seu intento não foi outro senão o de articular história e psicanálise de modo que ambas possam ter em vista os aspectos éticos e políticos que plasmam as sociedades. Não se trata, portanto, de patologizar as sociedades analisadas, e é nesse aspecto que interpreto o seu texto como uma ampliação fecunda do de Vinyes. Assim, a utiização das noções psicanalíticas não se darão, nesse caso, de um modo formalista, mas através de uma seleção que permita considerar os acontecimentos passados e presentes, sem deixar de visar o futuro.

Isso colocado, Lacapra passa à consideração de dois pares de conceitos psicanalíticos que não param de se comunicar. De um lado, as noções de luto e de melancolia que, segundo o autor, são cruciais para que relacionemos história e memória. De outro, os conceitos de

\footnotetext{
${ }^{28}$ RICOEUR, Paul. A memória, a história, o esquecimento. Campinas: Editora da Unicamp, 6. reimpressão, 2014, p. 91.

${ }^{29}$ Ibidem, p. 92.

${ }^{30}$ LACAPRA, Dominick. 'Psicoanálisis, memoria y el giro ético.' In: LACAPRA, Dominick. Historia y memoria después de Auschwitz. Buenos Aires: Prometeo Libros, 1. ed., 2009, p. 207-239
} 
elaboração e compulsão à repetição, que se articulam com os dois primeiros. ${ }^{31}$ Luto e melancolia guardam semelhanças entre si, uma vez que ambos pressupõem uma perda, seja essa a perda de uma pessoa ou mesmo de um ideal que deixa de estar disponível. Contudo, o trabalho de luto é mais desejável que o estado melancólico, na medida em que ele possibilita o reconhecimentodo do ente ou do ideal perdido, submetendo-se assim àquilo que Freud chamava de princípio da realidade. ${ }^{32}$ Já a melancolia pressupõe um desconhecimento do objeto perdido, constituindo portanto uma ameaça ao trabalho de luto. No coração do trabalho de luto observamos os efeitos benfazejos da elaboração; por sua vez, na melancolia é o mecanismo de compulsão à repetição que pode ser destacado. ${ }^{33} \mathrm{O}$ último conceito redunda de uma memória em excesso, uma memória traumática que não foi assimilada ou digerida. Assim, o indivíduo (ou sociedade, nessa transposição metafórica) acessa tal memória pela ação, isto é, repete-a sem dar-se conta disso. O mecanismo pelo qual tal ação é executada é denominado de passagem ao ato, que se contrapõe por sua vez ao trabalho de memória. Por outro lado, a elaboração, associada ao trabalho de luto, pressupõe uma lembrança, uma busca ativa realizada pela memória, denotando assim a noção de 'trabalho', que oferece a possibilidade de abordar frontalmente os problemas e eventos geradores de trauma e, da mesma forma, um controle responsável da ação que permita mudanças desejáveis, isto é, ligadas a ações eticamente responsáveis, baseadas num juízo crítico que escape dos efeitos de uma neurose melancóliconarcísica, abrindo-se ao outro. ${ }^{34}$ Assim, a elaboração é um processo direto e consciente, que opera através do trabalho de memória, enquanto que a compulsão à repetição é indireta e inconsciente, cujo mecanismo interno é o da passagem ao ato. ${ }^{35}$ Em conclusão, é legítimo pensar que o giro ético proposto pelo autor seja fruto de um movimento triplamente articulado: a associação da história com a psicanálise; a transposição no uso das ferramentas psicanalíticas da análise do indivíduo para a análise das sociedades (com os riscos e possibilidades que tal transposição encerra); um viés analítico que não seja estritamente epistemológico, mas que tenha em seu núcleo preocupações éticas e políticas na abordagem dos passados traumáticos.

\footnotetext{
${ }^{31}$ Naturalmente, não há espaço nesse ensaio para ver em detalhe a maneira como tais noções são formuladas e trabalhadas por Freud, de modo que vou me ater especificamente ao texto de Lacapra.

${ }^{32}$ LACAPRA, Op. Cit., p. 211.

${ }^{33}$ Ibidem, p. 212.

${ }^{34}$ Ibidem, p. 214.

35 A fim de evitar o risco de certo mecanicismo anaítico, cabe lembrar com Lacapra que embora o processo de elaboração seja preferível ao de passagem ao ato, nem sempre o trauma poderá ser superado por completo. Assim, o estado melancólico pode ser necessário na medida em que nele a perda é de alguma forma registrada (ainda que não se reconheça integralmente qual é o objeto perdido), de modo que a melancolia, nesses termos, pode ser vista como um pré-requisito ao luto. Ibidem, p. 211-213.
} 


\section{CONSIDERAÇÕES FINAIS}

Apresentados os argumentos que considero centrais nos textos a que me propus analisar, é chegado o momento de demonstrar, agora um pouco mais detalhadamente, o modo pelo qual os trabalhos de Cercas, de Vinyes e de Lacapra podem enfim ser articulados. Como assinalei anteriormente, o livro de Cercas tem uma vantagem e uma desvantagem quando comparado aos outros textos apresentados: tem a vantagem de ter alcançado um grande número de leitores na Espanha, dando assim maior visibilidade à importante discussão que gira em torno das memórias da guerra civil e da ditadura franquista. Sua desvantagem é a de ter uma abordagem analítica problemática, que vê a memória apenas como fenêmeno individual e a história como um campo do saber objetivo, que tenderia a construir uma verdade que Cercas chega a chamar de 'absoluta'. O caráter problemático dessa abordagem é mais ou menos óbvio: de um lado, é por estar ligada ao indivíduo e somente a ele que a memória, circunscrita à esfera privada, acaba por obstaculizar o debate público e cidadão apregoado por Vinyes sobre os passados traumáticos, de modo que se Cercas também critica duramente aquilo que ele denomina 'chantagem da testemunha', ele não oferece nenhum antídoto a esse fenômeno; de outro lado, e paradoxalmente, vemos que a história desenhada por Cercas é objetiva e capaz de chegar a verdades imparciais e 'perfeitas', fazendo da memória nada mais do que um de seus objetos. $\mathrm{O}$ paradoxo reside em que uma história como essa, objetiva e imparcial, poderia encerrar todo e qualquer debate, tendo como efeito o mesmo congelamento das discussões sobre os passados traumáticos que vemos na 'chantagem da testemunha'. Assim, portanto, nesse curioso distanciamento entre memória e história, ambas aparecem enfraquecidas e sobretudo incapazes de lidar com os passados traumáticos. A memória por estar centrada no indivíduo, sem abertura para o plural; a história, por seu turno, não só em razão de sua alegada e insuperável objetividade, mas também em virtude de que seu enfoque é empobrecedor, isto é, tão somente epistemológico ou cognitivo, ensimesmada que está e, sobretudo, desprovida de qualquer abertura para as considerações de ordem ética e política tão apregoadas por Vinyes e por Lacapra.

Pois bem, é justamete esse distanciameto entre história e memória que o texto de Vinyes corrige. Lançando mão de argumentos elaborados por Paul Ricoeur, ele dirá que a relação entre ambas deve ser de complementaridade, num diálogo de enriquecimento recíproco, haja vista que história e memória organizam suas buscas retrospectivas de modos distintos. Vinyes enfatiza que a história não produz conhecimentos acabados e perfeitos como quer Cercas, argumento que permite às discussões histriográficas vislumbrarem constantes atualizações. 
Outro ajuste importante ao texto de Cercas é que Vinyes aponta insistemente e com clareza que as memórias confinadas na vida privada dos cidadãos devem se tornar públicas, ou seja, coletivas. Essa abordagem traz consigo duas vantagens: permite que história e memória possam auxiliar-se mutuamente, além de considerar aspectos éticos e políticos nos saberes elaborados pela historiografia.

Por fim, o texto de Lacapra não é senão a última parte de um tripé que possibilita a articulação entre história, memória e psicanálise. Em certo sentido, é uma reatualização do texto de Vinyes (ao menos no modo como esses trabalhos estão elencados no presente ensaio), já que parte de uma mesma preocupação: superar passados traumáticos através de um debate público e articulado entre várias esferas do saber, sem separar os elementos epistemológicos dos éticos e políticos; mas trata-se igualmente de uma ampliação do trabalho do historiador espanhol, na medida em que traz consigo todo o arcabouço teórico da psicanálise, o que possibilita um recorte acadêmico distinto, mas apropriado e complementar, uma vez que estamos falando de passados traumáticos. Vinyes chega mesmo a assinalar em algumas ocasiões, utilizando o jargão pscicanalítico, que se as discussões sobre a guerra e a ditadura não se tornassem verdadeiramente públicas o trabalho de luto da sociedade espanhola estaria interrompido. $\mathrm{O}$ risco da interrupçao desse trabalho, no qual o papel da discussão pública poderia ser comparado ao conceito de elaboração, seria o de cair no estado melancólico, associado à compulsão à repetição. No entanto, Lacapra lembra que o trabalho de luto requer um contexto social que o sustente e que seja, portanto, solidário a ele. ${ }^{36}$ Como Vinyes nota com abundância de exemplos, uma atmosfera favorável ao trabalho de luto foi impossibilitada por reiteradas ações do Estado espanhol nas últimas quatro décadas. Articulando as leis de Anista e de Memória Histórica, Vinyes percebe que ambas tiveram como efeito a circunscrição da memória à vida privada. No que tange à Lei de Memória Histórica, tal circunscrição teria ocorrido em razão de que a lei de 2007 reconhece a vítima apenas no nível individual, fixando ademais a memória em torno do sofrimento, por si só intransmissível, eximindo-se assim de qualquer discussão pautada por parâmetros éticos ou políticos. Podemos metaforicamente falar, ao pensar nessas duas leis, de uma compulsão à repetição? Possivelmente, se nos ativermos em especial a um aspecto do passado recente espanhol e das memórias que giram, fantasmáticas, sobre ele: que boa parte da população desconhece as reais dimensões dos horrores da guerra civil e da ditadura, ${ }^{37}$ haja vista que o debate público foi duas vezes inibido. Primeiramente com a Anistia ampla e irrestrita de

\footnotetext{
${ }^{36}$ LACAPRA, Dominick. Op. Cit., p. 212.

${ }^{37}$ VINYES, Ricard. Op. Cit., p. 32.
} 
1977 e depois, em outubro de 2007, com a lei que iria propiciar o protagonismo tão criticado por Vinyes desse personagem que ele denomina de sujeito-vítima. Duas leis diferentes e espaçadas no tempo que resultam, porém, no mesmo efeito: na impossibilidade de uma discussão pública sobre os temas que traumatizaram a sociedade espanhola. Lembremos, enfim, que a compulsão à repetição é um processo associado ao estado de melancolia em que o enfermo não tem consciência do objeto perdido. É por isso que acredito na possibilidade de utilização desse conceito psicanalítico para a análise do passado recente espanhol. E é por isso que um livro como o de Cercas, apesar de seus problemas, pode vir a representar um instrumento entre outros para a elaboração do passado recente na Espanha, tornando pública uma discussão tão candente e, portanto, aumentando as chances de que uma ressignificação das memórias traumáticas seja de fato efetuada, como sugere Ricard Vinyes.

\section{Recebido em: 09/01/2018 \\ Aceito em: 05/03/2018}

\section{REFERÊNCIAS BIBLIOGRÁFICAS}

AGUILAR, Paloma. Justicia, política y memoria: los legados del franquismo en la transición española. In: Centro de Estudios Avanzados en Ciencias Sociales. Madrid: Series 2001/163, 60 páginas.

Disponível Los debates sobre la memoria histórica. In: Claves de Razón Práctica, $\mathrm{n}^{\circ} \mathrm{XX}$. https://www.academia.edu/9740546/LOS_DEBATES_SOBRE_LA_MEMORIA_HIST\%C3 \%93RICA. Último acesso em 10 out. 2016.

CERCAS, Javier. O Impostor. São Paulo: Biblioteca Azul, 1. ed., 2015;

CERTEAU, Michel de. A Escrita da História. Rio de Janeiro: Forense Universitária, 2. ed., 3. reimpressão, 2013.

HALBWACHS, Maurice. A memória coletiva. São Paulo: Centauro, 2. ed., 8. reimpressão, 2015.

HARTOG, François. A testemunha e o historiador. In: PESAVENTO, Sandra Jatahy (Org.). Fronteiras do Milênio. Porto Alegre: Ed. Universidade/UFRGS, 2001, p. 11-41.

LACAPRA, Dominick. Historia y memoria después de Auschwitz. Buenos Aires: Prometeo Libros, 1. ed., 2009.

. Trauma, Absence, Loss. In: Critical Inquiry, Vol. 25, n 4. Summer, 1999, p. 696-

727. Disponível em $\quad$ http://blogs.brandeis.edu/siis/files/2014/04/LaCapra_Trama_Absence_Loss.pdf. Último acesso em 10 out. 2016.

NIETZSCHE, Friedrich. Segunda Consideração Intempestiva: Da utilidade e desvantagem da história para a vida. Rio de Janeiro: Relume Dumará, 1. ed., 2003. 
PASAMAR, Gonzalo et al. Há estallado la memoria: las huellas de la Guerra Civil em la Transición a la Democracia. Madrid: Biblioteca Nueva, 1. ed., 2014.

RICOEUR, Paul. Tempo e Narrativa 1: A intriga e a narrativa histórica. São Paulo: Martins Fontes, 1. ed., 2. tiragem, 2012.

2012.. Tempo e Narrativa 3: O tempo narrado. São Paulo: Martins Fontes, 1. ed., 2. tiragem, 2014.

A memória, a história, o esquecimento. Campinas: Editora Unicamp, 6. reimpressão,

VINYES, Ricard (editor). El estado y la memoria: gobiernos y ciudadanos frente a los traumas de la historia. Barcelona: RBA Libros, S. A., 1. ed., 2009.

El sujeto-víctima en las políticas de reparación y memória. Disponível em: http://www2.al.rs.gov.br/escola/LinkClick.aspx?fileticket=nqXCDEEgc94\%3D\&tabid=2333. Último acesso em 10 out. 2016.

WIEVIORKA, Annette. The era of the witness. Ithaca: Cornell University Press, 1. ed., 2006. 